\title{
MELAYU PATTANI THAILAND: MUSLIM MINORITY RELIGION EXPRESSION IN THE MIDDLE OF NON MUSLIM MAJORITY
}

\author{
Arismunandar \\ Omdurman University, Sudan \\ Email: munandar@gmail.com \\ Afriantoni \\ Universitas Islam Negeri Raden Fatah Palembang \\ Email:afriantoni_uin@radenfatah.ac.id \\ Asmuni \\ Tarbiyah High School of Islamic Education Foundation Lahat \\ Email: asmunifalahul@gmail.com
}

\begin{abstract}
Pattani Province in southern Thailand is the only province with the majority of the Muslim population. Besides Pattani the majority of Thai residents (67 million people) are Buddhists. Only $10 \%$ of Thai people are Muslims, including Pattani's Muslim Malay minority. Some data suggest that the Thai government made policies that often discredited and did not accommodate the interests of Malay Muslims. This became one of the reasons for the emergence of opposition to Thai government and ethnicity. For example, must use the Thai language (thaification Program) reinforced by the prohibition of the use of Malay language and nationalization of Thai society culture through language and customs. The cultural policies relating to the use of Thai language and customs are intended to promote Thai nationalism, while they erode the identity (religion and culture) of Pattani Malay. The Malay minority resistance was led by the scholar Tuan Guru Haji Sulong Al-Fathani. He also acted as negotiator with the Thai government in order to fight for Malay Muslim aspirations. His negotiations resulted in a policy of the enactment of Malay language education as a curriculum material at Pattani National School.
\end{abstract}

Keywords: Pattani, Muslim minority, non Muslim majority

\section{Introduction}

Thailand is a country with a majority ethnic Thai population. However, it differs from the South Thai region which is divided into 4 provinces, namely Yala, Narathiwat, Pattani and Songkhla. Three of the four provinces are Yala, Narathiwat and Pattani people dominated by ethnic Malay Muslims. The Malay Muslim ethnic community living in the southern Thailand region reaches $80 \%$ of the total population there. This situation makes the social life of ethnic Malay Muslims in southern Thailand different from other regions. These 
MELAYU PATTANI THAILAND: MUSLIM MINORITY

RELIGION EXPRESSION IN THE MIDDLE OF NON MUSLIM MAYORITIES

Arismunandar, Afriantoni, Asmuni

differences include language differences, writings, and the Ordinances of life. (Malik Ibrahim 2012, 134).

Pattani is also often a term for "minority Muslims" that inhabit three southern regions of Thailand (Yala, Pattani, Narathiwat and part of Senggora). Since the 12th century Islam entered Pattani and later became a religion adopted by the majority of the population in the region. Later Islam colorize the political entity named Pattani Kingdom. The Kingdom of Pattani Raya (or better known by Thai Muslim population as Pattani Darussalam) was then taken over by the Kingdom of Siam. By Asep $(2016,31)$ This area (Pattani) begins with a sovereign Malay Islamic kingdom, the Islamic Kingdom of Pattani Darussalam. Then Pattani was put under force by the Thai government to become part of the Kingdom of Thailand in 1902. The region's geopolitical position is directly adjacent to Burma on the west and with the government of Malaysia in the south. Before becoming an Islamic sultanate, Pattani was successively ruled by the kingdom of Langkasuka, the Kingdom of Sriwijaya and Majapahit. According to the first governmental or government historical records in Pattani area is the Langkasuka kingdom, which was founded in the first century CE. The Kingdom of Pattani was held to receive Islam circa 1457 A.D. (M. Ahama 2017, 1).

Differences between Thai and Malay Muslims pose a problem. The problem begins with the treatment felt by ethnic Malay Muslims. This was once a citizen of Pattani kingdom. When switching to the government of Siam (Thailand) Ethnic Malay Muslims feel is being affected by various government policies. Therefore, some of Pattani's inhabitants did not want to acknowledge Thai rule over Pattani kingdom. This issue is then increasingly expanding. The act of protest and the movement of ethnonationalism by ethnic Malay Muslims led to violent violence.

Based on the background above this article will discuss how to form the Muslim minority religious expression Pattani amid the majority of non-Muslim Thai population. This article will also discuss how Pattani's Muslim community endeavours to claim freedom of religion, as well as how non-Muslim majority behavior of Pattani Muslims.

\section{Pattani Thai Malay in History Trails}


With a land area of 513,120 kilometers, Thailand is the largest 50 country in the world. In terms of population, Thailand is the 20th largest. The area is equatorial, where Thailand is a unique place that is difficult to find in other areas. The northern part of the country has a view of the mountains and the highest point of its range is Doi Inthanon at an altitude of 2,565 meters above sea level. On the northeast side is the Khorat plain bordered by the Mekong River. In the middle part of the country lies the Chao Praya basin flowing into the Gulf of Thailand. In the south there is the Kra Ishtmus River Valley which has expanded after flowing into Malaysia.

Thailand is a thriving country, where rivers are the main source of water. The Chao Praya River and the Mekong River are the main water resources. Thailand's coastal areas are well-preserved, as the tourism sector is a major contributor to the country's economy.

Other names of Thailand are Muangthai, or Muangthai Risabdah, or Siam, or the white elephant country. Geography of the country is located in North Malaysia. Thailand is an independent state, and the only country in southeast Asia that has never been explored by the power of the West or any other country. Thailand has a population of about 67 million the majority of Buddhism and $10 \%$ of its religion is Islamic. The Malay Muslim population is mostly located in southern Thailand, such as the province of Pha Nga, Songkhla, Narathiwat and surrounding areas that are historically part of Pattani Islamic region. As a minority of Muslims in southern Thailand it is not uncommon to get attacks from Buddhists (hardline Buddhas), intimidation, and even massacre (Ampera Pattani 2018).

In the early beginning, Pattani Muslims were known as an Islamic kingdom. In 1457, Pattani district has now populated predominantly Muslim Malay. Pattani's condition was similar to some of the surrounding areas such as Perlis, Kelantan, and others located in Malaysia. In 1875, the Thai first came to Pattani and immediately occupied the area. The British arrival to the Malacca Peninsula resulted in a treaty with Thailand, where Pattani was ruled by Thailand while Perlis, Kelantan and other territories were owned by the British. Then the British called the Colony with the designation Malaysia.

In the years 1904 and 1909, under two treaty Anglo-Siamese Treaties, Siam recognised four South Malay countries over Britain in exchange for the recognition of the Siamese sovereignty over Pattani. The last agreement led to a new period of foreign rule in Pattani 
MELAYU PATTANI THAILAND: MUSLIM MINORITY

RELIGION EXPRESSION IN THE MIDDLE OF NON MUSLIM MAYORITIES

Arismunandar, Afriantoni, Asmuni

which had major consequences for the Malay community and the religious and political authority in the south. There was a separation between Pattani and the Malay countries of Kelantan, Perlak, Kedah and Perlis (now Malaysia). In 1910, Pattani religious figures and Sufi sheik expressed jihad against the Siamese government and launched two rebellions. Both were extinguished by the military forces of Thailand and Malay Muslim leaders were arrested (C.A. 2007).

Ali Sodikin in Fatiwell $(2016,34)$ Added, historically, the political, cultural, and legal uprule in Pattani is very dynamic. In the beginning, Pattani was an independent form of the Islamic sultanate, but in the early 19th century it was annexed by the Kingdom of Siam. When Siam metamorphosed into a sovereign state with a Thai name that was a constitutional monarkhi (in 1932), Pattani became a province under Thai rule. When it becomes a province or region this is the dynamics of sosio-kultural in the culture of society. Their local culture, formed through the acculturation between Islam and Malay culture, has a new culture, which is the Thai culture. Between these two cultures there are fundamental differences that are difficult to integrate. Thus, there came a resistance from Pattani people to every integration effort or assimilation conducted by the Thai government.

In the historical explorations of Pattani, Yuniarto $(2005,105-106)$ said that the cultural conflict between Pattani people and Thailand was caused by the negative stigma of each group/ethnicity. Ethnic Thai considers ethnic Malay Muslims as a colot, or backward.

The cultural issues emerged from the identification of the stereotypes and stigma of Pattani society by the Thai government. An example of ethnic Thai Buddhist refers to Pattani with the word "Khaek" which literally means ' guest ' or ' entrant ' in Thailand. In general, the term "Khaek" is also used to identify people with special mature sawo skin that originated from South Asia such as: India, Pakistan, and the Middle East. In the ThaiBudhist view, the word "Khaek" refers to the term which smells as ethnocentric, and stereotypic. The word "Khaek" also connotation as lazy, scourge, selfish, poor, unbelievable, petty-minded, cruel, inoperative, stupid, unfriendly, and fanatical. Essentially the connotations contain the meaning of harassment.

Likewise, in contrast, South Thai Muslim Malay identifies Thai-Buddhist as infidels (atheist), sculpture (Buddha image). They are likened to modern ignorance, slaves "Latta and Uzza", which, according to Islamic law, must be fought because of wrongdoing, such as 
a monkey, oppressive, and fighting the Malays. Melayu Muslim Pattani itself identifies the relationship of Thai government with Pattani as the relationship between the oppressive (invaders) and the oppressed (colonized). From here among the ethnic Thai supported by the government of Siamese and Malay, Pattani has always happened social friction. They cannot be integrated due to a principle difference. With such a view the conflict between Pattani territory and the central government is often the case, and interethnic reconciliation is difficult.

According to Sateemae, et al, the main difference between Pattani Malay ethnicity and ethnic Siamese in addition to differences in religion, tradition, and culture is the political influence of assimilation of Thai government called Thaisification. The Thaification Program is reinforced by the prohibition of the use of Malay language and nationalization of Thai culture through language and customs. The cultural policies relating to the use of Thai language and customs are aimed at promoting Thai nationalism while eroded the identity (religion and culture) of Pattani Malay (Sateemae, Abdel-Monem 2015, 5).

Meanwhile, according to Fatiyah $(2016,36)$ A leader of Pattani student organization, firmly said, we strongly oppose the assimilation program of the Thai government. It is clear that there is no cultural accommodation politics against the minority. No government attention to Malay culture as part of national culture. The continuity of the Malay tradition and customs should not be banned by the government.

Before the merger of Pattani in the Siamese government, Pattani residents already had customs and culture that had been carried out according to Islamic law. This lasted in generations. However, after joining the state of Thailand they were always forced to obey the rules of the Government that were not in accordance with the Customs, culture and teachings of Islamic sharia.

\section{Pattani Muslim Minority Religious Expression}

A variety of information and data show that as a minority resident, Pattani Muslims in Thailand are unable to display a free expression. Various pressures of government policy 
MELAYU PATTANI THAILAND: MUSLIM MINORITY

RELIGION EXPRESSION IN THE MIDDLE OF NON MUSLIM MAYORITIES

Arismunandar, Afriantoni, Asmuni

have limited the expression and rights of running the traditions and religious teachings that the community believed.

In some cases, the term minority often connotation to something negative, such as sparatism and social anti-establishment. The term minority or minority people are usually used to demonstrate a small community of people living in a particular area and have different social and cultural traditions. These usually have certain characteristics that differ from other members of the community (majority) who reside in the same area. The term minority or minority people can classified through several different categories, one of which is a religion category. In the context of Thailand, the minority in question is those (Muslims) who live together with the majority (Buddhists). Although Muslims living in southern Thailand (Satun, Songkhla, Pattani, Yala and Narathiwat) are a minority community, but here is not only Thai Muslims in the south alone, but in general the Muslims in All over Thailand, both South and north.

Abdul Mutin bin Salman $(2015,20-21)$ says that the term minority in Thailand originated in a long history. It started with the founding of Pattani kingdom in southern Thailand. There was a annexation by the Siamese kingdom against Pattani Kingdom. This happened around 100 years ago. Although the inhabitants of Pattani kingdom often fought a fight, the Siamese government was able to make it. Meanwhile the efforts of the local population determine their own fate under international law is not so strong.

All the movements and insurgency that took place in Thailand began due to the mission of King Chulalongkorn to integrate the Malays of Pattani into the Thai administrative system. Without this integration he said, the effective government of Thailand is difficult to run. To do this required an extension of central bureaucracy in the area through the power of officials appointed by the central government in Bangkok. In 1906, four years after the transmission of the Malay kings from Pattani Malay Kingdom, he was made a merger of the Malay state of Pattani in a new Monthon (local administrative unit) under the name Monthon Pattani.

When tensions between the Thai government and the minority in the South increasingly made efforts to find a solution to the tension. As of March 2013, the peace talks between the Thai government and the minorities of the southern Pattani region entered a new chapter. Some Parties submit a peace note among them in the form of autonomy 68 
concepts. The great work of the Thai Government is to make these resistance groups come in and become an inherent part of government, not as a party to head to head with it. Perhaps the concept of autonomy that can be used as reference is some cases, such as in Aceh (Indonesia) and Moro (Philippines). The memorandum of understanding currently in Thailand is still not possible for the Muslim minority of Pattani to obtain his rights as a citizen.

Like other minority communities in this part of the world, the conflict between Thailand (Buddhism) and Melayu (Muslim) is always influenced by the dimension of majority government control over minorities. Most of the cases happening in Thailand are minority control by the majority through politics or other means. While the minority Muslims themselves often strive to create new power structures that can be controlled in a mandri. But unfortunately, to achieve that they often take separatist movements and have always failed.

\section{Non-Muslim Majority Behavior of Pattani Muslims}

Pattani Muslims were forced into part of Thailand when the country was still named the Siamese kingdom. However, due to the occupation, there was no turbulent unrest in Pattani area until now. A reasonable reaction because Pattani Muslims continued to fight. The suffering experienced by Muslims in southern Thailand has actually lasted for many years. Muslim minorities cannot live quietly because they are in the shadows of anxiety and the gripping life drama.

There has been a lot of blood bloodshed on Pattani earth. The facts show an indication that Pattani Muslim slaughter is almost exactly the same as it is happening in other Muslimeducated countries. For example, Pattani Muslims have been killed while praying in the mosque. As long as this bloody tragedy in Pattani is almost infrequent, it is because the Thai government does restrict and control all current information about Pattani. Many people consider Pattani's conflict only a matter of internal Thailand. In Pattani, interfaith harmony is rarely seen. It was mentioned that in the past, Pattani Muslims often gave food to the monks. But now it does not happen again. It happened because of the bad treatment often received by Pattani Muslims. 
MELAYU PATTANI THAILAND: MUSLIM MINORITY

RELIGION EXPRESSION IN THE MIDDLE OF NON MUSLIM MAYORITIES

Arismunandar, Afriantoni, Asmuni

Thai government's treatment of Pattani Muslims is bad. They are forbidden to store Pattani history books. Their historical consciousness was cut off by Thai government and military powers who were very concerned that the Muslims were aware that they were Malay people, and not Thai. They are strictly forbidden to speak Malay (Phaosan Jehwae 2018, 6-7). Rosana Jehma et al $(2017,71)$ Added that the Thai government's treatment led by Phibun grew wider by making a policy not pro against Malay Muslims, one of which is Ratthaniyom Thai's policy of requiring the daily language to use Thai language, both the introductory language in schools, formal education institutions and the names of the citizens, and closed the Islamic-based institutions which are in Malay language. In addition to language issues and history, they are also conditioned in an always gripping state with a variety of terror and intimidation. On every main road, it is always guarded by militaryuniform soldiers complete with automatic weapons.

\section{Pattani Muslim community Endeavour in demanding his rights}

Pitsuwan and Basari $(1989,186)$ explained that in the case of the Malay-Muslims in southern Thailand, there are three factors that attract international attention. Firstly, there is an ethnic affinity between the Malay Muslims of Pattani with almost 200 million people of Southeast Asian Malay race. Since the turn of the century, political leaders in Indonesia and Malaysia were concerned about the situation of their brethren who had not been freed from Thai rule. Secondly, there is a bond of Islamic religion that connects the Malay minority to the Islamic world. Thirdly, the ideological interests of other countries wishing to acquire allies from various guerrilla groups claiming to represent the aspirations of the Malay Muslims began to focus on the conflict in southern Thailand.

In 1915, a Pattani resistance named Abdul Kadir fled to Kelantan from which he remained a significant influence on the resistance. Among the resistance inspired by him was Namsai Rebellion in 1922, where the villagers of Namsai in Pattani's Mayo district, refused to pay land taxes to the Thai government in protest against the education reform introduced In 1921. Year 1921 is published compulsory elementary education LAW which requires all public elementary school children to learn Thai language. The enforcement of this rule is seen as a major insult to Malay Muslims and direct attacks on cultures, religions and languages. 
The public schools not only taught the secular curriculum in Thailand, but also Buddhist ethics lessons, with monks often serving as teachers. While attempts to replace Ponoh (huts) are thought to threaten not only socially and culturally, but also the economic strengths of religious teachers. A religious education figure called Tok Guru actively mobilizes communities against the policy. The parents of Muslims also refused to send their children to public schools. Villagers do a massive protest not only against the education policy, but also on the obligation to pay taxes. The government finally moved a local official, especially the unpopular and reduced taxation on Muslims while capturing and executing the alleged leaders.

The government pressure eased over the next decade, and the violence-was subduded. In June 1932 the absolute monarchy's power expired. The so-called "revolution of 1932" was driven by the concept of sovereignty of the people by nationality and nationality. This marked the journey with the next Thai political elite to build the Thai nation and the entire national identity, a symbol of Buddhism and the monarchy. Practically, this is a form of ethnic minority assimilation and centralization of power in Bangkok. For the first time Malay Muslims are now eligible to run for national parliamentarians. However, the national integration policy had ceased.

In 1939 Siam changed its name to Muang Thai with General Luang Pibulsongkram as prime minister and ruled from 1938 to 1944 . Tensions between Thailand and Malay Muslims took place again, and were exacerbated by the rise of Marshal Phibul Songkhram. Phibul was an ultra nationalist who emphasized the aggressive policy of assimilation that began in his early reign. In a series of decisions known as the cultural mandate, ethnic minorities including Malay Muslims, are forced to conform to the values of Thai culture.

Buddha images were placed in all public schools and Malay Muslim children were asked to bow in front of them to demonstrate their loyalty as citizens. Malay Muslims were banned from wearing traditional clothing in public and were forced to adopt Thai names as a prerequisite for government work. The use of Malay language is forbidden in government offices and the "anti-Thai" behaviour is classified as incitement against the law. Phibun's cultural decision was a direct challenge to the Malay Muslim identity. 
MELAYU PATTANI THAILAND: MUSLIM MINORITY

RELIGION EXPRESSION IN THE MIDDLE OF NON MUSLIM MAYORITIES

Arismunandar, Afriantoni, Asmuni

Malay charactery influenced by Islamic teachings is quite significant for regional Muslims. The Islamic scholarly tradition was carried out and disseminated by scholars or religious scholars who sincerely supported the Da'wah of Islam in the archipelago. In the colonial era we have seen a figure named Master Haji Sulong Al-Fathani, a figure who has played an important role in leading Muslim society to face misery due to non-Islamic world hegemony. The arrival of Western colonizers to southeast Asia could not change the worldview, especially in response to the challenges and tribulations faced by the Malay countries that became the target of colonial expansion. Among those who play an important role in the process of Islamization in the Malay Archipelago are Pattani scholars.

Haji Sulong Al-Fathani was one of Pattani scholars who had left many valuable works, including the book Light Security Cluster. The book was written when he was in the Legor prison. Cluster Light Security was completed written on 3 Zulkaidah 1368 which coincides with the date of 28 August 1949. The book's first print of 10,000 thousand manuscripts was done by Haji Sulong's son Haji Muhammad Amin.

Mr. Guru Sulong Al-Fathani was appointed as the chairman of Pattani Islamic Religious Council. The designation was given to the Malay Muslim figure to coordinate and facilitate the administrative pathways of Islamic law in the region. He is also responsible for seeking data and information relating to the existence of Malay Muslims as well as presenting the views, recommendations, and aspirations of southern Thai Muslims to the authorities. The second role he played was thus negatively impacting the Malay Muslims, as the Siamese government then moved master of teachers to Khuan Apaiwong area. The new policy was to enact Malay language education in national primary schools and to restore economic efforts in the Muslim-majority region of southern Thailand.

The thought of Mr. Guru Haji Sulong is very influential in the development of Islamic idealism and thought renewal. He said the modern generation needs to explore and embrace the identity and roots of the Islamic heritage retained and preserved so that the values in life become strong. As the words of Mr. Guru Haji Sulong Al-Fathani: "The luster of the peasants can be realized to organize and benefit Muslims in Kelantan in particular and the archipelago in general". He said that be a person who is able to organize well in all aspects of life and can benefit many people especially in Kelantan, and generally for other Muslims. 


\section{Conclusion}

Pattani is one part of Thailand in the south with a majority of Malay Muslim population. They have hereditary traditions and customs that become customary in everyday life since the era of Pattani is still a kingdom of its own. When the kingdom of Pattani was forced by the Siamese kingdom of the majority of Buddhists, Pattani was made one of the Thai government areas. The Government of Siam (Thailand) enforces policies that are perceived to suppress Pattani's Malay Muslim rights, both from language, cultural, religious and socio-political aspects. This policy raises a Malay Muslim resistance (Pattani) which is a minority against the Thai Government (Siam) the majority. Malay Muslim expression that is minority can be accommodated through the struggle of religious figures and academics, especially Tuan Guru Sulong Al-Fathani. He negotiated with the Thai Government on the civil rights owned by the Malay Muslims in Pattani. The struggle to return the civil rights of Pattani Malay was realized through the inclusion of Malay language education in the National Elementary school, and the Thai Government had an interest to improve the economy in the southern Thailand region. 
MELAYU PATTANI THAILAND: MUSLIM MINORITY

RELIGION EXPRESSION IN THE MIDDLE OF NON MUSLIM MAYORITIES

Arismunandar, Afriantoni, Asmuni

\section{Bibliography}

Ampera Pattani. 2018. "Sejarah dan Perkembangan Islam di Thailand." https://amperaPattani1992.blogspot.com/2018/02/sejarah-dan-perkembangan-islamdi.html\%0A\%0A.

Asep Achmad Hidayat. 2016. Studi Kawasan Muslim Minoritas Asia Tenggara. Bandung: Pustaka Rahmat.

C.A., Thayer. 2007. Insurgency in Southern Thailand.

F. Fatiyah. 2016. "Perspektif Muslim Thailand Tentang Nasionalisme Etnis Dan Agama: Studi Persepsi Mahasiswa Pattani Di Yogyakarta." Kontekstualita 32 (2).

M. Ahama. 2017. "Perkembangan Persatuan Intelek Cinta Seni Budaya Di Pattani (Thailand Selatan) Pada Tahun 2012-2016. Bandung: UIN Sunan Gunung Djati.

Malik Ibrahim. 2012. "Seputar Gerakan Islam Di Thailand Suatu Upaya Melihat Faktor Internal Dan Eksternal." Sosio-Religia 10 Nomor 1.

Paulus Rudolf Yuniarto. 2005. “Minoritas Muslim Thailand; Asimilasi, Perlawanan Budaya Dan Akar Gerakan Separatisme." Jurnal Masyarakat dan Budaya 7 (1).

Phaosan Jehwae. 2018. “The Role Of Malay Language And Literature As A Media For Peace In Pattani Thailand And The Archipelago." Journal of Malay Islamic Studies 2 nomor 1: 67. http://jurnal.radenfatah.ac.id/index.php/jmis/article/view/2549/1872.

Pitsuwan, S., \& Basari, H. 1989. Islam Di Muanghthai: Nasionalisme Melayu Masyarakat Pattani. LP3ES.

Rosana Jehma, Sumardi, Sugiyanto. 2017. "The Nationalism Movement of Islam for Independence of Pattani Southern Thailand." Jurnal Historica 1 (1): 71.

Salman, B., Lc, M. A., \& Matin, H. A. 2015. Pemikiran dan Model Gerakan Islam Minoritas Thailand (Studi Antropologi-Fenomenologi). Surakarta: IAIN Surakarta.

Suhaimee Sateemae, Tarik Abdel-Monem, Mahsoom Sateemae. 2015. "Religiosity and Social Problems among Muslim Adolescents in Southern Thailand." Journal of Muslim Mental Health 9 (2): 5. 